PF 2020 (75/1): 437-452

https://doi.org/10.32798/pf.672

\author{
JAKUB SLÁMA \\ Department of Contemporary Lexicology and Lexicography \\ Czech Language Institute of the Czech Academy of Sciences, Praha \\ e-mail: slama@ujc.cas.cz \\ ORCID 0000-0002-6555-0471
}

\title{
THE SKEWED FREQUENCY HYPOTHESIS AND THE IDENTIFICATION OF VALENT NOUNS IN ENGLISH ${ }^{1}$
}

\begin{abstract}
I propose the Skewed Frequency Hypothesis, according to which the distribution of corpus types following immediately after the occurrences of a valent noun is significantly skewed, unlike with avalent nouns. The question explored in this paper is whether this observation can be used to retrieve a list of valent nouns from a corpus. Two simple ratios are used to measure the skewness of the distribution of types, and it is shown that the two ratios are correlated and serve as somewhat reliable cues of noun valency. The cases are discussed in which the two ratios suggest conflicting results, and it is argued that these cases serve as one of the arguments for viewing noun valency in English as a scalar phenomenon rather than a binary possibility (valent vs. avalent). Finally, I also discuss some other issues concerning noun valency in English, and based on the data, I suggest treating noun valency in terms of Construction Grammar.
\end{abstract}

KEYWORDS: argument structure, Construction Grammar, colligation, complements, noun valency

SŁOWA KLUCZOWE: struktura argumentowa, gramatyka konstrukcyjna, koligacja, określenia predykatywne, walencja rzeczowników

1 The preparation of this article was financed within the statutory activity of the Czech Language Institute of the Czech Academy of Sciences (RVO No. 6837809). 


\section{Introduction}

If an English noun has a valency frame (or, an argument structure), thus requiring an argument, this argument is typically expressed as a complement that takes the form of a prepositional phrase or another unit introduced by a grammatical word. It therefore follows that valent nouns might colligate with certain grammatical words. Based on this, I propose what I refer to as the Skewed Frequency Hypothesis: a valent noun should enter colligational relations, based on which the frequency distribution of the types following the noun in a corpus should be skewed, and the position immediately following the noun should be less variable (type-wise) than after an avalent noun. I attempt to operationalize the relevant variables and, using data from the British National Corpus ${ }^{2}$ (BNC), to test whether this hypothesis can prove useful for the identification of valent nouns in a corpus.

\section{Background}

In this section, I first elaborate on the central concept of noun valency (2.1), and after briefly discussing the relevant phenomenon of colligation (2.2), I illustrate what I refer to as the Skewed Frequency Hypothesis, explaining its rationale and its relevance to the procedure of identifying valent nouns in English (2.3).

\subsection{Noun valency and complementation}

Semantically, two types of nouns can be distinguished: sortal nouns and relational nouns. Sortal nouns simply denote (or classify) entities, e.g. chair and table (Plag 2003 , p. 148). Relational nouns, on the other hand, "denote relations between a specific entity and a second one" (Plag 2003, p. 148). For example, father and surgery are relational nouns because, respectively, to qualify as a father, one has to be a father of someone (or, metaphorically, of something), and a surgery always has to be performed on something. This necessary "something" is linguistically expressed as a complement (or, to use a different term, an argument) of the relational noun; the terms complement and argument are often used interchangeably (e.g. Resi 2014, p. 170). Even though both of these terms "can refer to an element in the semantic representation and also to a syntactic entity" (Van Valin, LaPolla 1997, pp. 27-28) and, being ambiguous, might require further discussion, in this paper I will simply use argument to refer to the above-mentioned necessary "something" on the semantic level, and complement to refer to the syntactic entity

2 The BNC was accessed through the KonText interface of the Czech National Corpus project, available online from $<$ https://kontext.korpus.cz $>$. 
referring to the argument. Thus, in the father of modern linguistics, father is a relational (and hence, in my view, valent) noun, of modern linguistics is its complement, and modern linguistics refers to the argument of the noun father.

The obvious question follows of how to differentiate a complement of a noun from an optional modifier, exemplified respectively in the destruction of the rainforests and rainforest destruction in the Amazon Jungle. Apart from my intuition (as to what nouns clearly do not have valency), I will rely here on the dialogue test and on the contextual non-boundness test. If one says My friends have already arrived and another person asks where the friends have arrived, I don't know is not a felicitous answer, and thus the goal is considered as an obligatory argument - this is the point of the dialogue test (Panevová 2014, p. 5). Similarly, based on the dialogue test, one can say that e.g. the noun attempt requires an argument:

(1) Many of these species perished in the attempt. (BNC) - The attempt to do what? The attempt at what? - ${ }^{\star}$ I don't know.

This relates to what I have referred to as the contextual non-boundness test, whose relevance I have illustrated elsewhere (Sláma 2018a; Sláma 2018b). The usual claim is that the complement of a noun is never obligatory (e.g. Lieber 2018, p. 109), but I have shown that when a valent noun is contextually non-bound, its complement can in fact be obligatory. For example, when one examines the instances of an ability in the written subcorpus of the BNC in which an marks the first use of the noun whereby its referent is introduced into the discourse (thus excluding e.g. instances of the semi-anaphoric such an ability), it turns out that every single one of these 230 instances of an ability has an overt complement. Therefore, it seems justified to claim that ability indeed has valency - contrary to some traditional accounts which attribute noun valency only to complex event nominals, a claim made most influentially by Grimshaw (1990, p. 45).

\subsection{Colligation}

As Lehecka (2015) points out, the term colligation "has been used in a large number of different senses" (also cf. Hoey 2005, p. 43). Nowadays it seems to be the case that when studying colligation, linguists most often focus on textual colligation, i.e. the fact that lexical items "are primed to occur in or avoid, certain positions within the discourse" (Hoey 2005, p. 13). This is the type of colligation that is examined in many corpus studies, including, for instance, the one by Dong and Buckingham (2018). However, I use the term colligation in the sense pioneered by Firth (1968, p. 182), who talks of "the interrelation of a set of grammatical categories transcending the actual words which may fall into those categories." Very generally, this means that, for instance, nouns colligate with adjectives and 
verbs tend to colligate with adverbs; but, importantly for this paper, this can also be applied to individual phrases or words, and one can for example state that the noun window tends to colligate with prepositions (Baker et al. 2006, p. 36), as witnessed by contexts such as casual passers-by, looking in the window at the menu (BNC). Since patterns of noun complementation are more or less limited to to-infinitives, prepositional phrases, and that-clauses (Hunston, Francis 1999, p. 6), it is clear what kinds of words might be expected to be found immediately after valent nouns.

\subsection{The Skewed Frequency Hypothesis}

Based on the discussion above, I assume that table is a sortal noun that lacks valency properties, and that ability is a good example of a relational noun that requires an argument. If we use the written subcorpus of BNC to investigate the colligations ${ }^{3}$ of these two nouns by a rather crude heuristic, i.e. by looking at what the most frequent lemmas are following the nouns (including punctuation), we get the following results:

\begin{tabular}{|l|l|l|l|}
\hline \multicolumn{2}{|c|}{ table } & \multicolumn{2}{c|}{ ability } \\
\hline. & 2,835 & to & 5,371 \\
\hline, & 2,354 & of & 1,132 \\
\hline and & 1,427 & . & 657 \\
\hline be & 599 & , & 579 \\
\hline in & 513 & and & 469 \\
\hline others & 12,843 & others & 1,734 \\
\hline total & 20,571 & total & 9,942 \\
\hline
\end{tabular}

Table 1. The lemmas most frequently following table and ability in the written BNC

At first blush, there is an obvious difference: while more than half of the instances of ability in the written BNC subcorpus are followed by to and roughly $65 \%$ of the instances of ability are followed either by to or by of, no such dominant pattern can be identified for table. The three most frequent lemmas (excluding punctuation) given in the table account for $12.3 \%$ of the instances of table (including those followed by punctuation), while for ability the proportion is $70.1 \%$.

3 By looking at the most frequent lemmas, one seems to focus on collocations rather than colligations; however, as McEnery and Brezina (2019, p. 98) note, "while it is often convenient to think of collocations and colligations as discrete categories, they should more properly be viewed as two poles of a lexicogrammatical continuum, meaning that it is almost inevitable that, in searching for meaning through collocation, we will uncover grammatical information." 
One does not need statistical significance testing to see that the difference can hardly be due to chance.

The question explored in this paper is whether a similar difference can be reliably found across English nouns, and, when turned "inside out", whether this observation can be used to retrieve a list of valent nouns from a corpus.

\section{Data}

To collect data, I used the written subcorpus of the BNC, first extracting a list of all nouns from the subcorpus ordered by frequency.

It is a well-documented fact that more frequent words tend to be polysemous (cf. Divjak, Caldwell-Harris 2015, p. 57), i.e. "the different usages or 'meanings' of a tool or word increase with frequency" (Zipf 1949, p. 109), and since my approach here is form-based, polysemy might distort the results; therefore, I decided to exclude the 426 nouns from the list that are attested in the subcorpus more than 10,000 times (a rather arbitrary limit) and thus seem most prone to polysemy. Furthermore, the dataset would ideally be of limited size so that it could be examined manually in detail, and so I excluded the nouns from the list that are attested in the subcorpus fewer than 5,000 times (again, this is a rather arbitrary threshold). Finally, I excluded the lemma no, abbreviations (e.g. $m$. and fig.), and proper nouns, which are "in a way 'intransitive' and cannot therefore have any arguments" (Resi 2014, p. 164-165), including e.g. Germany, September, America, James, West ${ }^{4}$, and english (sic).

For each of the 436 remaining lemmas, I extracted a) its frequency, b) the number of various types occurring in the $\mathrm{R} 1$ position (i.e. following immediately after the noun), and c) the lemmas and frequencies of the three most frequent grammatical words in the R1 position. I added to the data set three columns: the sum of the frequencies of the three most frequent grammatical words, the ratio of this sum and the total absolute frequency of the lemma, and the ratio of the number of types in the R1 position and the absolute frequency of the lemma. For convenience sake, I will refer to the former ratio as $r_{1}$ and to the latter ratio as $r_{2}$. For instance, ability is most frequently followed by to, of, and and, as mentioned above, and the instances of ability to, ability of, and ability and account for $70.1 \%$ occurrences of ability; $\mathrm{r}_{1}$ for ability is thus roughly 0.7. Overall, ability is followed by 327 different types, and so with its absolute frequency of 9,942 occurrences, its $r_{2}$ is roughly 0.03 .

4 Arguably, however, North, East, South, and West, although lemmatized as proper nouns in the BNC, seem to take arguments; cf. Sláma and Štěpánková (2019) on the valency of the corresponding adverbs in Czech. 
The interpretation of $r_{1}$ and $r_{2}$ is rather straightforward: the higher the $r_{1}$ for a noun, the more often is the noun followed by one of the three lemmas occurring most frequently in the R1 position, and the higher the $r_{2}$ for a noun, the higher the relative number of different lemmas immediately following the noun.

Finally, I intended to annotate each of the 436 nouns for its type (sortal vs. relational), but this turned out to be rather problematic; while the distinction is typically clear with the usual textbook examples, its application to a sample of nouns seems rather subjective and hence problematic in a plethora of cases. Therefore, I did not include this distinction in the data set.

\section{Results}

At first blush, the two ratios seem to be somewhat suggestive of whether the noun requires a complement (and thus has an argument structure). For instance, while $r_{1}$ is highest for lack (0.98), variety (0.76), proportion (0.73), absence (0.71), and combination (0.70), which could be considered (mostly not controversially) as valent, the ratio is very low for nouns such as sir (0.004), football (0.091), telephone (0.093), metal (0.102), and cash (0.118), which can be described as not requiring a complement. Similarly, $\mathrm{r}_{2}$ is lowest for arguably valent nouns such as lack (0.01), importance (0.03), and ability (0.03), and highest for clearly avalent nouns such as metal (0.25), adult (0.16), and gold (0.16).

Furthermore, it is not surprising (yet it is not self-evident either) that there is a negative correlation ${ }^{5}$ between the two $\operatorname{ratios}^{6}(\mathrm{r}(434)=-0.6768693 ; \mathrm{p}<2.2 \mathrm{e}-16$, the $95 \%$ confidence interval of correlation is [ $-0.7247141,-0.6225289]$ ), summarized in the following scatterplot (Figure 1), where each data point corresponds to one noun. Since the two ratios are correlated, they should serve as comparably reliable indicators of whether a noun has an argument structure. In the following two sections, I will thus focus on the reliability of the ratios and on the cases in which the ratios suggest contradictory results (i.e. one suggests that the noun might be valent and the other suggests the opposite).

5 To analyze the data, I used R, a free software environment for statistical computing (R Development Core Team 2008).

6 The values of both ratios are normally distributed - with the sample size of $\mathrm{N}=436$, this is not necessary to test, but still, the Shapiro-Wilk normality test confirms that the values are indeed normally distributed $\left(\mathrm{r}_{1}: \mathrm{W}=0.8745, \mathrm{p}<2.2 \mathrm{e}-16 ; \mathrm{r}_{2}\right.$ : $\left.\mathrm{W}=0.98029, \mathrm{p}=1.199 \mathrm{e}-05\right)$. 


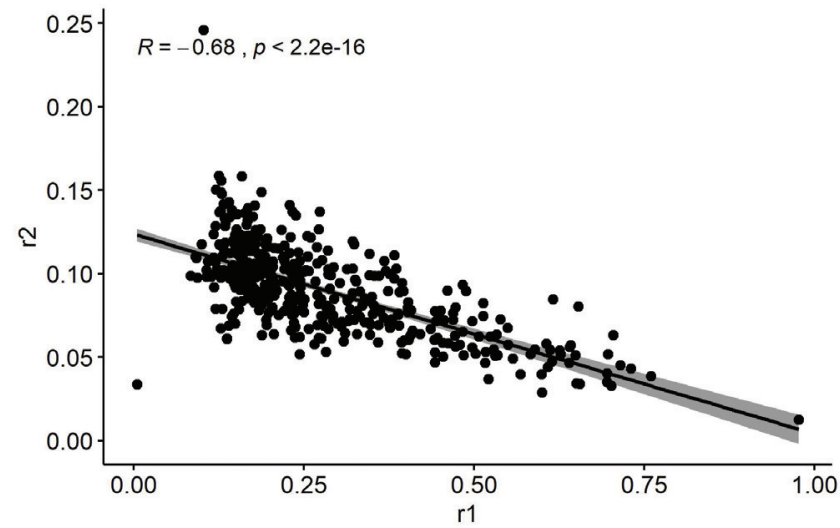

Figure 1. The correlation between $r_{1}$ and $r_{2}$

\subsection{Reliability of $\mathbf{r}_{1}$}

As stated above, higher values of $r_{1}$ are to be found with nouns that are typically followed by a grammatical word (typically a preposition) introducing a complement. The thirty nouns with the highest $r_{1}$ include:

\begin{tabular}{|l|l|l|l|l|l|}
\hline \multicolumn{1}{|c|}{ noun } & \multicolumn{1}{c|}{$\mathbf{r}_{1}$} & \multicolumn{1}{c|}{ noun } & \multicolumn{1}{c|}{$\mathbf{r}_{1}$} & \multicolumn{1}{c|}{ noun } & \multicolumn{1}{c|}{$\mathbf{r}_{1}$} \\
\hline lack & 0.977 & introduction & 0.653 & means & 0.612 \\
\hline variety & 0.760 & possibility & 0.650 & intention & 0.608 \\
\hline proportion & 0.731 & $\begin{array}{l}\text { understan- } \\
\text { ding }\end{array}$ & 0.649 & copy & 0.606 \\
\hline absence & 0.715 & access & 0.642 & importance & 0.600 \\
\hline combination & 0.704 & bit & 0.640 & emphasis & 0.599 \\
\hline ability & 0.701 & implication & 0.640 & sign & 0.589 \\
\hline reduction & 0.696 & majority & 0.627 & desire & 0.582 \\
\hline beginning & 0.695 & impact & 0.625 & consequence & 0.568 \\
\hline rise & 0.695 & pair & 0.616 & commitment & 0.557 \\
\hline aim & 0.655 & presence & 0.615 & concept & 0.550 \\
\hline
\end{tabular}

Table 2. The thirty nouns with the highest values of $r_{1}$

If one applies the tests mentioned above, all the nouns seem to qualify as valent. For instance, there cannot be a lack unless it is the lack of something, and this is reflected in the fact that from the 1,104 instances of a lack in the written BNC, 1,089 are immediately followed by of, two are false positives (A lack lustre scheme; If $A$ lacks the legal capacity...), and the remaining examples either do not feature 
a lack as new in the discourse (cf. example 2, in which the semi-anaphoric such a lack is actually preceded by another instance of lack, from which it is clear the lack whereof is at stake), or feature a generalized use of lack (3), comparable to the intransitive use of verbs with indefinite null complements such as eat - and just like the intransitive use of eat does not disqualify the verb from having an argument structure, we should acknowledge that examples like (3) do not disqualify nouns like lack from having one:

(2) Sweeney shocks because he shows so clearly the effect of lack of themis. Harrison had written of such a lack among the Cyclopes. (BNC)

(3) It acts as a supplement to a lack, something missing, on the part of the signified thing. (BNC)

Therefore, based on the dialogue test and on the related test concerned with context boundness, discussed above, lack can be seen as valent - and the same applies to all the other nouns in Table 2. However, what is rather interesting is the fact that it applies to the nouns in varying degrees. While lack and ability, when preceded by the indefinite article marking contextual non-boundness, seem to require an overt complement, with a noun like copy the situation is not as straightforward. The phrase a copy is followed by of only in 1,589 (74\%) of its 2,136 occurrences in the written BNC subcorpus, and while in the remaining examples a complement can often be found (4), there are still instances when there simply is not one, as in (5):

(4) It is the one of which a copy is used today. (BNC)

(5) The completed NEWOED2 form should be returned to the New OED Computer Group representative making sure a copy is retained. (BNC)

In (5), it is clear that a copy refers to a copy of the aforementioned form, but the noun is still used with the indefinite article and without an overt complement. Based on the dialogue test, however, we can maintain that copy requires an argument and is, indeed, valent.

Table 3 gives the thirty nouns for which $r_{1}$ reaches the lowest values:

\begin{tabular}{|l|l|l|l|l|l|}
\hline \multicolumn{1}{|c|}{ noun } & \multicolumn{1}{c|}{$\mathbf{r}_{1}$} & \multicolumn{1}{c|}{ noun } & \multicolumn{1}{c|}{$\mathbf{r}_{1}$} & \multicolumn{1}{c|}{ noun } & \multicolumn{1}{c|}{$\mathbf{r}_{1}$} \\
\hline gold & 0.1284 & drug & 0.1226 & speaker & 0.1086 \\
\hline crown & 0.1282 & media & 0.1209 & phone & 0.1071 \\
\hline screen & 0.1280 & prison & 0.1205 & afternoon & 0.1067 \\
\hline winter & 0.1279 & nation & 0.1204 & metal & 0.1024 \\
\hline pension & 0.1278 & blood & 0.1203 & railway & 0.0999 \\
\hline silence & 0.1277 & radio & 0.1200 & telephone & 0.0936 \\
\hline
\end{tabular}


The Skewed Frequency Hypothesis and the identification of valent nouns in English $\quad 445$

\begin{tabular}{|l|l|l|l|l|l|}
\hline \multicolumn{1}{|c|}{ noun } & \multicolumn{1}{c|}{$\mathbf{r}_{1}$} & \multicolumn{1}{c|}{ noun } & \multicolumn{1}{c|}{$\mathbf{r}_{1}$} & \multicolumn{1}{c|}{ noun } & \multicolumn{1}{c|}{$\mathbf{r}_{1}$} \\
\hline traffic & 0.1259 & cash & 0.1177 & consumer & 0.0920 \\
\hline weekend & 0.1259 & league & 0.1175 & football & 0.0905 \\
\hline acid & 0.1257 & cabinet & 0.1170 & insurance & 0.0838 \\
\hline adult & 0.1251 & while & 0.1136 & sir & 0.0046 \\
\hline
\end{tabular}

Table 3. The thirty nouns with the lowest values of $r_{1}$

While most of the nouns are rather clearly avalent sortal nouns, there are some less clear cases. For instance, crown can be found in phrases such as a crown of thorns, a crown of wild flowers, and the like, in which the status of the of-phrase might be somewhat disputable (but it seems appropriate to conclude that the phrase is a modifier, not a complement, based on the dialogue test, among other things). The noun winter is perhaps best seen as avalent; however, in some literal as well as metaphoric contexts in which winter receives a meronymic (i.e. part-whole) interpretation, it does take what seems to be a complement:

(6) The underlying cause for this decision was the awful damage caused by the savage winter of 1709. (BNC)

(7) When a man reaches the winter of his life, there's nothin' he can look forward to but death. (BNC)

Another problem might be presented by the noun silence, which seems to be mostly avalent, but in some contexts takes a complement:

(8) Lord Donaldson said that he could now break the traditional silence of judges about their colleagues... (BNC)

The noun weekend is also noteworthy: while it is typically used without a complement, in some contexts it seems to parallel some valent nouns, referring to containers (9), including e.g. a cup of tea, and some meronyms (10), i.e. nouns referring to parts of something, that can be seen as valent, including part itself but also winter in examples 6 and 7:

(9) a weekend of celebration (BNC)

(10) the weekend of the first week of September (www.dailystar.co.uk)

Finally, blood, speaker, and consumer can be used with of-phrases which seem to possibly qualify as complements (even though in (11), the of-phrase might be seen as a modifier, and according to the dialogue test, it does not seem to be obligatory):

(11) they wore robes stained scarlet from the blood of their victims (BNC)

$7 \quad$ Retrieved from Fulda 2020. 
(12) native speakers of English (BNC)

(13) the greatest consumers of wheat fibre are the Slavs (from Yugoslavia) (BNC)

Scrutiny of the complete dataset suggests that $r_{1}$ is rather reliable in that the nouns with $r_{1}$ of 0.25 or higher ${ }^{8}$ can be (mostly not controversially) considered as valent. However, the discussion above illustrates that the reliability of the ratio is somewhat limited in that a lower value of the ratio does not guarantee that the noun cannot take a complement.

\subsection{Reliability of $\mathbf{r}_{2}$}

As stated above, the two ratios are correlated; however, there are some notable discrepancies between them. For instance, the avalent noun sir with a very low $r_{1}$ has the fourth lowest $r_{2}$, following only after three clearly valent nouns, lack, importance, and ability. Similarly, while e.g. discipline, past, peace, silence, public, accident, and smile are expected to be avalent based on their $\mathrm{r}_{1}$ values, they rank among clearly valent nouns according to $r_{2}$. While these nouns (for a brief discussion of silence, see the previous section) seem to be mostly avalent, in some contexts some of them appear to take a complement (note, however, the coordination of training and discipline in (14)):

(14) the poor training and discipline of the security forces (BNC)

(15) a dark stain on the past of a very important German industrialist (BNC)

(16) the peace between Greeks was breaking down too (BNC)

(17) brief knowing smiles of senior academics on committees (BNC)

On the other hand, some nouns, including location, victim, transfer, guide and publication, would be expected to be valent based on their $r_{1}$ values (and also based on the dialogue test) but rank as avalent if $r_{2}$ is used.

In conclusion, while $r_{1}$ and $r_{2}$ correlate and seem to be relatively useful indicators of argument structure when trying to extract a list of valent nouns from a corpus, their reliability is far from absolute. Interestingly, when the two ratios are in conflict, $r_{1}$ of 0.25 or more is generally a good marker that the noun is likely to be valent, but when $r_{1}$ is lower and the noun seems not to have valency, although $r_{2}$ suggests that it could be expected to take a complement, the noun generally seems not to take a complement, but occasionally does.

8 Nouns with $r_{1}$ just above this threshold include distance (0.251), surface (0.255), reading (0.256), base (0.267), and author (0.269). Nouns with $\mathrm{r}_{1}$ just below this threshold include culture (0.244), truth (0.243), facility (0.243), crowd (0.241), and pain (0.238). Naturally, however, the value of 0.25 is not a strict threshold dividing all valent nouns from all avalent nouns. 


\section{Discussion}

What I see as the most important point implied in this paper is the observation that it might be more adequate to treat noun valency as a scalar phenomenon, rather than a binary one. That is, while the traditional approach consists in stating that a noun does (or does not) have valency properties and thus takes (or does not take) a complement, a different view might be somewhat more appropriate. It seems to be clear that some nouns, like ability, do have an argument structure, while others, like coffee, do not ${ }^{9}$. However, with slight semantic changes, the valency properties might be affected: when ability is used to mean 'ability in general, ability at anything one can have ability at', typically in texts on education, as in (18), it does not seem to require an argument (just like lack in example 3 above):

(18) Thus an ability represents what a person can do now, whereas a capacity is essentially a potential. (BNC)

Furthermore, there seem to be a host of nouns which sometimes seem to require an argument (or, less frequently, arguments), but typically do not - often without obvious semantic changes. For example, there are 865 instances of the form selfie in the Corpus of Contemporary American English ${ }^{10}$ (COCA), and some of the 29 of those of them followed by of seem to be very good examples of selfie followed by a complement, e.g.:

(19) Luliana had been contractually obligated to post a selfie of her eating a slice of pink cake with glitter frosting (COCA)

(20) a selfie of the two of them in some restaurant (COCA)

(21) A brave model from London managed to save herself from a life-threatening hostage situation after secretly sending a selfie of her bruised, battered face to a friend. (COCA)

This might be taken to mean that selfie requires an argument, perhaps on analogy with nouns such as photograph; after all, the dialogue test tells us that this is the case (Can we take a selfie? - Of whom? - ${ }^{\star}$ I don't know.). However, I think it is rather questionable whether it is useful to say that selfie has an argument structure when it is in fact dispreferred to use an overt complement (apart from the numbers given above, it also seems rather unusual to say something like $I$ will take a selfie of myself), and in an informal poll I drew among ten linguists, seven answered that they would not see selfie as a valent noun in English. It is not clear whether it is more adequate to treat selfie as avalent, admitting that it still

9 In phrases like a coffee of the iced variety (taken from the Corpus of Contemporary American English (Davies 2008), the of-phrase is clearly a modifier, not a complement.

10 Available online from <https://www.english-corpora.org/coca/ $>$. 
occasionally takes what seems to be a complement (and that the dialogue test might not be exactly helpful here), or to treat selfie as valent, while acknowledging that this is somewhat futile, given the fact that the noun typically does not, or possibly even cannot, take an overt complement.

To give another example, it is quite common for certain nouns referring to entities that can be conceptualized (and used) as containers to vacillate between being avalent (22) and taking an argument (23):

(22) you broke her mug (COCA)

(23) He'd return with a mug of tea. (COCA)

A noun like backpack is not typically followed by a complement (only 39 of the 6,324 instances of the form backpack are immediately followed by of in COCA), but when it is, the of-phrase can be quite naturally interpreted as a complement on a par with the complements of other container nouns:

(24) I know this individual had a backpack of explosives. (COCA)

Arguably, this is not enough for backpack to be seen as polysemous, and so the traditional assumption that a change in valency equals a change in meaning is not particularly helpful here - in part because such an approach is rather circular, claiming that the predicate has multiple valency frames because it has multiple meanings, and at the same time deriving the claim that the predicate has multiple meanings from the observation that it has multiple valency frames; cf. Goldberg (1995, p. 11).

Generally, having valency is usually equated with taking a complement (or complements) referring to an argument (or arguments). Hellan et al. (2017, p. 1) state explicitly that "the notion 'argument', traditionally used in the logical disciplines, has become equivalent to 'valency-bound'." To illustrate this, it can be mentioned that, for instance, Klímová et al. (2016, p. 1) define noun valency as "the number, type and form of arguments that are bound to a noun." The equation of having argument structure and requiring an argument is implied in the definitions of valency in general, cf. e.g. Haspelmath and Hartmann's $(2015$, p. 42) delineation: "The valency of a verb is the range of syntactic properties of other elements of the clause that depend on the particular choice of verb, i.e. that are verb-specific. These other elements of the clause are called arguments."

However, some nouns (like backpack) seem not to be valent, but still take an argument, without necessarily being polysemous. I believe that the problem has a rather obvious solution: we can admit that a sortal noun, albeit not inherently valent, can enter a syntactic construction on analogy with semantically similar nouns that are often used in the construction, and the construction can 
contribute an argument. This is in fact rather common with verbs, as illustrated in the large body of research conducted within Construction Grammar, with Goldberg (1995) as one of the pioneering works in this regard. For instance, the verbs sneeze, smile, and laugh are typically intransitive, but they may enter various argument structure constructions, in which they appear to have a new valency without any change in lexical meaning (the examples are cited after Goldberg (2006, p. 6)):

(25) He sneezed his tooth right across town.

(26) She smiled herself an upgrade.

(27) We laughed our conversation to an end.

Again, if one claims that e.g. sneeze in (25) has a new sense ('to cause something to move by sneezing'), one commits the circularity fallacy mentioned above, proposing this new sense only on the basis of the unusual valency frame, but also using this presumably new sense to explain why the verb occurs in the unusual valency frame.

Goldberg and others use examples like (25), (26), and (27) as one of the arguments for a constructionist view of argument structure rather than the lexical(ist) view $^{11}$ (which is based on the notion that the valency of a lexical unit is determined by the lexical unit alone). For related reasons, Haugen (2013) argues that valency of adjectives supports a constructional approach to valency, and I believe that the points raised above might present a good argument for a constructional approach to noun valency too.

A noun like backpack is primarily sortal and avalent, but when it enters the construction with the container interpretation, the construction contributes what appears to be a complement of the noun. Since the noun does not have the container interpretation unless it is used in the construction, what might be perceived as a new meaning is more adequately seen as a property of the whole construction, not of the lexical item alone. This description avoids what has been called the polysemy fallacy, i.e. viewing contextually-bound uses of a lexical item as instances of polysemy (Haugen 2013, p. 63). On the constructional view, the noun has only one meaning, but it can be used in various constructions, which can lead to slightly different semantic interpretations of the same sense of the noun.

To summarize the discussion, noun valency in English appears to be more adequately treated as a scalar phenomenon (rather than a yes-no phenomenon), and nouns that appear to be inherently avalent sometimes seem to be able to

11 "The basic idea behind lexical models of valency is that the predicator, the valency carrier, determines how it is to be complemented. However, individual predicators are typically found in several valency patterns, and this is also valid for adjectival predicators." (Haugen 2013, p. 47) 
take arguments contributed by a construction possibly associated with a specific interpretation (e.g. the container interpretation or the meronymic interpretation), but not necessarily with a new meaning. I have also suggested that in view of the data presented above, noun valency (in English) might be described more adequately within the constructionist framework.

\section{Sources}

The British National Corpus, version 2 (BNC World). Distributed by Oxford University Computing Services on behalf of the BNC Consortium. Institute of the Czech National Corpus, Prague 2001. Available online from <http://www.korpus.cz $>$. Last accessed August 15, 2020. (BNC)

Davies, M. (2008). Corpus of Contemporary American English. Available online from $<$ https://www.english-corpora.org/coca/>. Last accessed August 15, 2020. (COCA)

Fulda, O. (2020). Premier League 2020/21 season 'must start by first week of September. Daily Star online. Retrieved from <https://www.dailystar.co.uk/sport/football/ premier-league-202021-season-must-21887626>. Accessed August 3, 2020.

\section{Bibliography}

Baker, P. et al. (2006). A Glossary of Corpus Linguistics. Edinburgh: Edinburgh University Press.

Divjak, D., Caldwell-Harris, C. (2015). Frequency and Entrenchment. In: E. Dąbrowska \& D. Divjak (eds.), Handbook of Cognitive Linguistics (53-74). De Gruyter Mouton.

Dong, J., Buckingham, L. (2018). The textual colligation of stance phraseology in cross-disciplinary academic discourse, International Journal of Corpus Linguistics, 23(4), 408-436.

Firth, J.R. (1968). A synopsis of linguistic theory, 1930-1955. In: F. Palmer (ed.), Selected Papers of J. R. Firth 1952-1959 (168-205). London: Longmans.

Goldberg, A.E. (1995). Constructions. A Construction Grammar Approach to Argument Structure. Chicago: The University of Chicago Press.

Goldberg, A.E. (2006). Constructions at Work: The Nature of Generalization in Language. Oxford: Oxford University Press.

Grimshaw, J. (1990). Argument Structure. Cambridge: MIT Press.

Haspelmath, M., Hartmann, I. (2015). Comparing verbal valency across languages. In: A.L. Malchukov. B. Comrie (eds.), Valency Classes in the World's Languages (41-71). Berlin: De Gruyter Mouton.

Haugen, T.A. (2013). Adjectival valency as valency constructions: Evidence from Norwegian, Constructions and Frames, 5(1), 35-68. 
Hellan, L. et al. (2017). Issues in contrastive valency studies. In: Hellan, L. et al. (eds.), Contrastive Studies in Verbal Valency (1-24). Amsterdam: John Benjamins Publishing Company.

Hoey, M. (2005). Lexical Priming: A New Theory of Words and Language. London: Routledge. Hunston, S., Francis, G. (1999). Pattern Grammar: A Corpus-driven Approach to the Lexical Grammar of English. Amsterdam: John Benjamins.

Klímová, J. et al. (2016). Towards a Corpus-based Valency Lexicon of Czech Nouns. In: GLOBALEX 2016: Lexicographic Resources for Human Language Technology. GLOBALEX Workshop 2016 (1-7).

Lehecka, T. (2015). Collocation and colligation. Handbook of Pragmatics Online. <https:// benjamins.com/online/hop/articles/col2>.

Lieber, R. (2018). English Nouns. The Ecology of Nominalization. Oxford: Oxford University Press.

McEnery, T., Brezina, V. (2019). Collocations and colligations: Visualizing lexicogrammar. In: B. Busse, R. Moehlig-Falke (eds.), Patterns in Language and Linguistics (97-124). Berlin-Boston: De Gruyter Mouton.

Panevová, J. (2014). Contribution of valency to the analysis of language. In: O. Spevak (ed.), Noun Valency (1-17). Amsterdam-Philadelphia: John Benjamins Publishing Company.

Plag, I. (2003). Word-Formation in English. Cambridge-New York: Cambridge University Press.

R Development Core Team (2008). R: A language and environment for statistical computing. $R$ Foundation for Statistical Computing. Austria: Vienna.

Resi, R. (2014). Noun phrasal complements vs. adjuncts. In: O. Spevak (ed.), Noun Valency (161-182). Amsterdam-Philadelphia: John Benjamins Publishing Company.

Sláma, J. (2018a). The prepositional phrase with the preposition at as a valency complement of nouns. MA thesis. Prague: Faculty of Arts.

Sláma, J. (2018b). K (ne)obligatornosti valenčního komplementu anglických substantiv. In: Kulturní a jazykový prostor v proměnách 21. století. Sborník príspěvků z konference ProfiLingua 2018 (129-142). Pilsen: University of West Bohemia.

Sláma, J., Štěpánková, B. (2019). On the Valency of Various Types of Adverbs and Its Lexicographic Description, Jazykovedný časopis, 70(2), 158-169.

Van Valin, R.D., LaPolla, R.J. (1997). Syntax, Structure, Meaning and Function. Cambridge: Cambridge University Press.

Zipf, G.K. (1949). Human Behavior and the Principle of Least Effort. Cambridge, Mass.: Addison-Wesley Press. 


\title{
SKEWED FREQUENCY HYPOTHESIS I IDENTYFIKACJA RZECZOWNIKÓW WALENCYJNYCH W JĘZYKU ANGIELSKIM
}

\begin{abstract}
ABSTRAKT: W niniejszym artykule przedstawiam skewed frequency hypothesis, według której dystrybucja typów korpusowych następujących bezpośrednio po wystąpieniu rzeczownika walencyjnego jest znacząco skośna, w przeciwieństwie do rzeczowników niewalencyjnych. Kwestią rozpatrywaną w niniejszym artykule jest ukazanie, czy ta obserwacja może być zastosowana do wyszukiwania w korpusie listy rzeczowników walencyjnych. W celu zmierzenia skośności rozkładu typów zostały zastosowane dwa proste wskaźniki i wykazano, że owe dwa wskaźniki są skorelowane oraz stanowią w miarę niezawodne wskazówki walencji rzeczowników. Omówiono przypadki, w których dwa wskaźniki wskazują sprzeczne wyniki, i stwierdzono, że owe przypadki stanowią jeden $\mathrm{z}$ argumentów przemawiających za tym, aby uznać rzeczowniki walencyjne w języku angielskim za zjawisko skalarne zamiast możliwość binarną (walencyjny vs niewalencyjny). Na koniec omówiam także kolejne kwestie dotyczące walencji rzeczowników w języku angielskim i na podstawie danych proponuję traktowanie walencji rzeczowników z punktu widzenia gramatyki konstrukcyjnej.
\end{abstract}

